\title{
THEFT AND SMUGGLING OF PETROLEUM PRODUCTS
}

\author{
Tim Eaton
}

The petroleum sector is highly complex. It produces a vast array of products, from cooking gas to heat homes and prepare food, to fuel for commercial vehicles and aviation fuels. Extensive expertise and infrastructure is required to extract, refine, move and store petroleum products. Internationally, the oil market is regulated: sellers not recognised by the international community and/or subject to restrictive measures are prohibited from dealing with buyers and traders, although they may find means to circumnavigate these measures. The sector involves a wide array of stakeholders, from politicians who pass legislation over the governance of the sector, to technocrats and engineers who are responsible for managing and running it, to security guards and truck drivers who may be responsible for safeguarding the products.

The world consumes in the region of 34 billion barrels of petroleum products per annum. The market value of each barrel of crude oil has fluctuated significantly in recent years. At 2017 prices, the market value was estimated to be $\$ 1.7$ trillion (Oilprice.com: 2017). The size of the oil market creates significant economic incentives to profiteer illicitly from the sector, and such profiteering takes place at all levels of the supply chain. In 2016, illicit trading in oil via underinvoicing, theft, bunkering and corruption was believed to account for nearly $\$ 100$ billion a year on the continent of Africa alone (African Development Bank: 2016: p. 7). In keeping with the theme of this handbook, this chapter will focus on the smuggling of petroleum products across national borders, but it necessarily will look at the means through which this is facilitated by factors at the national-level. It should be noted that the smuggling of these products is inextricably connected to theft (i.e., the products are diverted from the supply chain via theft and subsequently smuggled) particularly at the upstream and midstream level. Therefore, the modalities of that theft are also covered here.

Drawing on a wide range of case studies in Europe, Africa, the Middle East and the Americas, the chapter will address smuggling of both refined and unrefined products, by working through the levels of the supply chain, first examining how upstream elements, such as the laws and governance of the oil sector, can be used, or abused, to facilitate smuggling. Next, means of smuggling oil products will be explored - the midstream elements of the supply chain beginning with the tapping and siphoning of unrefined oil. Diversion of refined products from the midstream and downstream elements of the supply chain will then be assessed, through bunkering and trucking. 
Analysing the supply chain, the actors that are in control of each element, and the operating environment in which the activities take place, is an effective way of illustrating how different forms of oil and fuel smuggling function. Such an analysis can reveal much about the underlying power relations in the state in question, the capacities of its institutions and the reach of its capacities for enforcement. While it is helpful to identify when and how petroleum products are diverted from the supply chain and smuggled by identifying upstream, midstream and downstream phases, the reality is that smuggling dynamics tend to be fluid and may be present at all levels. This chapter consequently explores contemporary fuel smuggling dynamics in Libya to illustrate how smuggling can permeate the upstream, midstream and downstream elements of the fuel sector. See Box 19.1 for details of different modalities of fuel smuggling.

The overall takeaway of this analysis is that the challenges associated with preventing smuggling become greater as the degree of penetration of the profiteers of up the supply chain increases. If, for example, smuggling networks have penetrated the governance of the petroleum sector upstream by cutting deals with officials in positions of authority to limit oversight or to actively facilitate smuggling, then 'fixing' the problem will depend on a more complex array of interventions than smuggling which is limited to activity in the downstream sector.

\section{Greasing the wheels: upstream governance of petroleum production}

The environment in which the petroleum sector operates has a critical impact over the nature and degree of fuel smuggling. While the term "upstream" is used within the oil and gas sector to refer to exploration and production, it is used more broadly here to refer to the governance of the petroleum sector (including the political system, the legal framework and the security situation). Actors present in the upstream level include state officials and legislators, and state and non-state enterprises. The ability of political and military representatives of the state to determine who can engage in oil smuggling allows them to profiteer from the smuggling of the state's assets through kickbacks and to cut deals with local actors in return for looking the other way. Moreover, when governments are prevented from selling to formal international markets, fuel smuggling can be state sanctioned as a means of generating revenues through informal and illicit means. The connivance of such officials with smuggling and the failure to ensure robust and transparent governance of the oil sector is a major facilitator of smuggling.

Some of these upstream dynamics are illustrated in Nigeria, where interests in the oil sector have become intimately connected to elite bargaining over political power. Nigeria is estimated to lose $\$ 3-8$ billion a year from oil theft and smuggling (Katsouris \& Sayne: 2013: p. 17). This is the equivalent of around $10-20 \%$ of the country's annual production. Oil theft and smuggling in Nigeria developed in the 1970s and 1980s while the country remained under military rule. Oil theft allowed military officers to sustain themselves while also allowing others to engage in the practice as a form of rent, thereby ensuring stability. The return to civilian rule in the $2000 \mathrm{~s}$ and subsequent steep global rise in oil prices stimulated greater competition over the sector. This led to the involvement by a broader array of actors, making the lucrative sector both a source of political deal making and a source of conflict (Katsouris \& Sayne: 2013: pp. 5-6). Under the administrations of Olusegun Obasanjo (1999-2007), Umaru Musa Yar'Adua (2007-2010) and Goodluck Jonathan (2010-2015), powerbrokers with close involvement in smuggling activities were benefactors of the presidents, who in turn shielded their benefactors from being held accountable for their smuggling activity (Burgis: 2015: pp. 73-79). This protection extended beyond the benefactors themselves to those in their networks: oil thieves and smugglers have been repeatedly protected from prosecution by the Nigerian authorities, (Katsouris \& Sayne: 2013: pp. 5-6). Numerous modalities of smuggling exist, including the 


\section{Box 19.1 Modalities of oil and fuel theft}

Retailing: buying at a subsidised rate and selling at an unsubsidised rate, profiting from price differentials between different markets.

Tapping: diverting supplies from oil pipelines and/or wellheads. There are two different types: "hot tapping" or "pressure tapping" is where small amounts are diverted from the pipelines without significantly reducing the pipeline's high pressure. On the other hand, "cold tapping" involves disactivating part of a pipeline and then placing a new tap in while the pipeline is down. When the pipeline is brought back online the new tap is not noticeable.

Siphoning: fuel is siphoned out and the supply is topped up with other products, such as kerosene or water to mask the missing amount.

Adulteration: In cases where fuel is dyed for use by agricultural machinery, the fuel is adulterated by mixing in other products in order to change the colour. This allows the fuel to be sold at higher prices to the broader consumer market. Other more complex processes exist for removing isotope markers (used to identify where the fuel is rebated).

Bunkering: illegally supplying ships with fuel to be sold on the black market or misrepresented on the formal market.

Trucking: illegal trafficking of fuels in specialised vehicles such as oil tankers, pick-up trucks and specially modified cars with significantly expanded fuel tanks.

Source: Adapted from Ralby (2017) 'Downstream Oil Theft: Culprits, Modalities, and Amounts',

Atlantic Council

tapping of oil pipelines and the illicit bunkering of ships, and then the subsequent smuggling of the oil.

In areas of countries that the state is unable to control, local actors can be granted rights to smuggle oil products in return for security guarantees. For example, in the 2000s, the Ugandan government had limited control in some of its territory. In some of these areas where the government had limited influence, the so-called 'Opec boys' smuggled fuel from the Democratic Republic of Congo with the consent of local Ugandan politicians as part of an alliance between the two sets of actors that allowed the politicians to maintain stability and for the Opec boys to sooth their grievances, generate revenues and leverage their capacity to rebel (Lecoutere and Titeca: 2007: pp. 1-37).

In other cases, there are incentives for political leaders to circumnavigate international regulations in order to profit from smuggling. Overland smuggling and maritime smuggling of crude oil in Iraq developed under the guidance of the regime of President Saddam Hussein in the 1990s. Starved of revenues from international oil sales as a result of the international sanctions regime and so-called "Oil for Food" measures, the regime actively found means of diverting crude to the black market to be trucked into neighbouring Jordan, Syria and Turkey (Eaton et al.: 2019: p. 13). This provided a significant revenue stream for Hussein's regime. Other attempts by governments not recognised by the international community to smuggle oil have been less effective. Libya had two rival governments from 2014 to 2021 . The government operating in the east of the country, unrecognised by the international community, sought to export crude oil repeatedly. These efforts, which effectively constitute large scale efforts to smuggle oil, have failed owing to the threat of violations of international law being levied at those who purchase the oil. 


\section{Midstream diversion and smuggling of unrefined products}

For the purposes of this chapter, midstream activities include the processing, storing and transporting of unrefined petroleum products. The distinction between midstream and downstream smuggling, between refined and unrefined products, is an important one. This is because the oil must be refined - or "finished" - to fulfil its function; i.e., for the crude to become diesel or heating oil. As a result, unrefined products are of lesser monetary value, necessitating either the sale of the product to actors that have access to refining capacity or possession of that capacity - and expertise - within the smuggling network.

The actors directly engaged in diversion of petroleum products midstream are those that have physical control over oil and gas infrastructure, the transportation network (usually pipelines), or the territory through which the products must pass. These include corrupt officials, security actors and criminal networks. The two principal means of diversion from the supply chain and subsequent smuggling are the physical capture of oil and gas infrastructure and the tapping of oil pipelines.

\section{Control of oil and gas infrastructure and the sale of unrefined products}

Actors that control oil and gas infrastructure but lack the access to technical expertise and facilities to refine fuel face limitations over their ability to sell the product. Following its capture of oil infrastructure in Syria and Iraq, the Islamic State of Syria and al-Sham (ISIS) was making significant profits from the running of oil fields and refineries, and subsequent smuggling of fuel to areas of Syria under the control of President Bashar al-Assad and also through pipelines to Turkey (Eaton et al.: 2019: p. 14). In response, the international coalition to counter the group decided to bomb the refineries under ISIS control. This led to the development of improvised methods to refining the fuel, such as digging a hole in the ground and flaring the oil to refine it in a rudimentary fashion. The fuel obtained through this process was of a significantly poorer quality and consequently sold for a much lower price (Eaton et al.: 2019: 52).

Greater sophistication is noted in the Nigerian smuggling sector to navigate the challenges associated with the theft of unrefined products. In Nigeria, crude oil appears to have been transported to artisanal refineries both within and outside of the country in the Nile Delta. In 2014, a refinery in Ghana was found to have produced five times its anticipated output of refined fuels due to the alleged input of smuggled Nigerian crude. The scheme required the complicity of actors associated with the Ghanaian production industry (Faucon: 2014), demonstrating the need for significant technical expertise for midstream smuggling.

\section{Access without full control: tapping of unrefined products}

For those actors who do not control fully territory that houses oil and gas infrastructure, the tapping of well-heads and pipelines is a means of large scale theft and subsequent smuggling. It can be done in two principal ways: "hot tapping" or "pressure tapping" involves fitting a tap to a high-pressure pipeline in order to divert a relatively small amount of the product. Some of these tapping operations, such as those that take place under water in Nigeria require significant expertise and are difficult to detect. The oil that is tapped either goes directly to artisanal refineries or so-called "mother ships" that may deliver the oil to other refineries, transfer it to other ships or unload it into storage (Ralby: 2017: 19). Perhaps as much as 10\% of Nigeria's exports are tapped per day (Ralby: 2017: 19), pointing towards the industrial scale of these activities. 
A more rudimentary alternative, "cold tapping," involves disabling or blowing up parts of pipelines and then fitting a tap as the pipelines are repaired, leaving the oil company unable to detect the tap. This approach has been used widely in Mexico, where the tapping and siphoning of pipelines carrying refined fuels of state-owned Petróleos Mexicanos (PEMEX) is a major challenge for the authorities (Ralby: 2017: p. 20). Organised crime groups are reported to bribe and coerce PEMEX employees to gain access to facilities where they can fit taps above- and under-ground in order to access fuel for their own purposes and to sell, as the sector has increasingly become controlled by large cartels. The number of illicit taps increased from an estimated 132 in 2001 to 12,582 in 2018, according to Pemex (Jones and Sullivan: 2019: p. 7). The tactics of the cartels have ended in disaster on some occasions. In one incident, 135 people were killed in an explosion as a result of an illegal tap in Tlahuelilpan, Hidalgo (Jones and Sullivan: 2019: p. 7). In 2011, PEMEX sued 11 U.S. companies for buying up to $\$ 300$ million of stolen fuel that it said was trucked across the U.S.-Mexico border (Rosenberg: 2011).

\section{Liquid cash: downstream smuggling of refined products}

Downstream smuggling refers to the smuggling of refined (finished) products, for the purposes of this chapter. As at the midstream, the actors directly engaged in diversion of petroleum products are those that have physical control over oil and gas infrastructure, the transportation network and/or access to the territory through which the products must pass. Unlike the midstream, however, there are fewer barriers to entry in downstream smuggling, which also allows for the participation of smaller networks of smugglers and individual smugglers, particularly in the movement and sale of the product. Unlike the institutional players (such as heads of companies, and leaders of organised criminal networks) who may be making significant profits, the actors actually moving and selling the product on the lowest echelons of the supply chain are likely to be dependent on smuggling for their survival.

Refined products can be sold direct to the public or the private sector for consumption. The principal means of profiting from the sale of smuggled refined fuels is retailing, while profits can also be increased by adulterating smuggled low value products to imitate high value products.

\section{Price differentials: retailing}

Retailing does not necessitate theft. For smugglers who are retailing, profit is obtained by selling for a higher price than that at which they bought the fuel. The incentive to smuggle refined fuels such as gasoline across international borders is usually driven by the difference in prices between neighbouring states. Differentials between prices in neighbouring states are exacerbated by subsidy regimes. Large oil producing countries such as Venezuela, Nigeria and Libya use such subsidies to provide low-cost fuel to their populations, creating significant margins for those who move the subsidised fuels across the border. In 2018, it was reported that fuel smuggled into Colombia from Venezuela increased in value 37,000-fold as a result of Venezuela's financial crisis and subsidy regime, generating profits of $\$ 3$ million a day for organised crime groups (Insight Crime: 2018).

The smuggling of gasoline from Libya to Tunisia in relatively small amounts via modified cars with oversized fuel tanks or via pickups carrying jerry cans of gasoline is long established, and the subject of informal regulation between Libyan and Tunisian counterparts (Gallien: 2020). The subsidised rate of gasoline in Libya was much as seven times cheaper than gasoline at the pump in Tunisia in 2018, offering a significant margin to smugglers (Eaton: 2018: p. 14). Such margins create opportunities for an array of actors, from individual smugglers, and individual criminal networks to state officials. 


\section{Adulteration}

After being smuggled across borders, low grade fuels are sometimes adulterated to imitate higher value products for onward sale to consumers to increase profits. This can be achieved by mixing other agents, such as ethanol into the fuel, or by mixing it with higher grade fuel. A prominent example of large-scale adulteration of fuel is found in Ireland. Irish fuel prices, particularly for agricultural grade diesel, made it highly profitable for criminal groups to adulterate the fuel and sell it across the border in Northern Ireland, with only very limited technical knowledge required. The practice was prevalent in the period following the 1998 peace agreement between the governments of the United Kingdom and Ireland, when border controls were relaxed. In 2002, the United Kingdom's Customs and Excise authority estimated that 450 of 700 petrol stations in Ireland were selling illicit fuel. Losses to the UK Treasury from fuel duty fraud were estimated at $£ 450$ million in 2000 (Irish Times: 2002). However, the margin obtained by the smugglers in the following decade was reduced significantly by the increase of fuel duties in Ireland and the reduction in the exchange rate from Euros, used in Ireland, to Sterling, used in the United Kingdom (Northern Ireland Assembly: 2012).

\section{Anatomy of the fuel smuggling sector in Libya: leaks at all levels in the supply chain}

While it is helpful to identify when and how petroleum products are diverted from the supply chain and smuggled by identifying upstream, midstream and downstream phases, the reality is that smuggling dynamics tend to be fluid and may be present at all levels. Contemporary dynamics in Libya illustrate how smuggling can permeate the upstream, midstream and downstream elements of the fuel sector. Since the overthrow of the regime of Muammar Gaddafi in 2011, the fuel smuggling sector has expanded from a cross-border activity to one that also determines the distribution of fuel in many areas within the country, as Libyans are less able to access state subsidised fuel.

A series of upstream problems plague Libya's fuel sector. State officials are likely to be profiting directly from smuggling through their official positions. A number of executives employed by state-owned entities also hold positions in private companies that profit from the fuel sector: a clear conflict of interest. In addition, a fractious security environment makes it nearly impossible for the authorities to enforce the law. The idiosyncrasies of the Gaddafi-era system of governance also make it difficult for state institutions to work together effectively. For example, the state electricity provider can requisition fuel from the state fuel company unilaterally, and payment for consumption is by no means ensured (Pack: 2021). Oversight is limited, as illustrated by the mechanism for calculating market demand, which is based upon the requirements submitted by sellers rather than data on market needs. Sellers are thus incentivised to inflate their requirements. Moreover, many of the sellers exist only on paper. When, in 2018, the National Oil Corporation spot-checked 105 new gasoline stations registered since 2010, it found that 83 of them did not exist (Eaton: 2019). These have come to be known as 'ghost' stations.

These factors have driven a massive increase in the import of refined fuels (needed because Libya can meet only $20 \%$ of its fuel needs with its own refineries) since the revolution. Figures obtained from the Libyan National Oil Corporation indicate a 30\% increase in the amount of gasoline being imported from 2010 to 2016. These increases are not explicable by market demand, indicating that demand was being exaggerated and the level of diversion in the system was on the rise. In 2017, the Libyan authorities assessed that around one-third of fuels such as 
gasoline and diesel are diverted to the market each year (Libya Observer: 2017). This is around 1.3 million tonnes, the equivalent of 178 Olympic-sized swimming pools (Eaton: 2019). In truth, though, the scale of diversion is unknown. Record keeping and public disclosure of statistics and figures is limited at best.

The leaks extend into the mid- and downstream of the fuel sector. The largest refinery in Libya is in north-western Libya, in the city of Zawiya. At the time of writing, it remains controlled by an armed group that has its origins in Libya's civil war. The Nasr Brigade, a revolutionary group, was transformed into a unit of the Libyan state's Petroleum Facilities Guard in 2013, placed onto the state payroll, and officially put in control of the Zawiya refinery. The refinery is a centre of smuggling activity. False paperwork is provided to truck drivers to make shipments destined for the black market look legitimate (especially if the destination station is a 'ghost' station) and the absence of accurate production figures makes it very difficult to ascertain how much of the fuel is being diverted. The National Oil Corporation's inability to control the territory its facilities are located in is a major problem. Similar issues exist at storage facilities, where officials and the armed groups guarding them can make significant profits from diverting the fuel to the black market.

Moreover, in the downstream sector, even fuel that is destined for the formal market must be moved over ground, often through areas controlled by armed actors who may hijack or confiscate some or all of the shipment. This is a particular problem in the south of the country, where a checkpoint economy has developed and armed groups apply informal taxes for the movement of goods to bolster their income.

The result of this activity is that Libyans are not benefitting from the fuel subsidies for which the state is paying in excess of $\$ 4$ billion a year. In many areas of the country, particularly the south, it has become near impossible for locals to obtain fuel at subsidised rates, and they are instead forced to buy from the black market. Black market rates can be up to 15 times that of the official subsidised rates. "I filled my tank for 6.5 dinars (around \$4.50) in Tripoli, 44 dinars (\$31) in Sebha (southern Libya), and when I reached Ubari (southern Libya) it cost me 75 dinars (\$53)," a driver told Chatham House researchers in August 2019 (Eaton: 2019).

These internal Libyan dynamics have led to shifts in the patterns of cross-border smuggling of fuel. Prior to 2011, the cross-border smuggling of fuel to Tunisia was well established, while Libyan fuel is also smuggled across the eastern border to Egypt and across its southern border to Niger, Chad and Sudan. The changes in Libya's smuggling has an impact on overland smuggling to Tunisia. Tunisian smugglers, who have to traverse the difficult operating environment in Libya, find it more difficult to obtain the fuel at low cost. Smugglers report having to deal with armed actors to obtain the fuel, and being charged inflated rates. Moreover, following the 2015 attack on the Tunisian border town of Ben Guerdane, border security has been increased on the Tunisian side. This has made it more difficult for smugglers to move fuel across the border, especially via desert routes. The impact of these shifts has been illustrated in the market, where prices of Libyan fuel increased four-fold between 2015 and 2019 (Eaton: 2019).

The smuggling of gasoil from Libya via maritime routes to Malta offers a greater margin than the aforementioned overland routes, expanding rapidly after the revolution. In 2015, Italy's Guardia di Finanza initiated operation 'Dirty Oil' in Sicily, targeted at fuel smugglers (Trial International: 2020). The operation led to the arrest of suspects in Libya, Malta and Italy. In Libya, the smuggling network was headed by Fahmi Salim Ben Khalifa, a native of the town of Zuwara, until his arrest in 2017. Salim's status in Zuwara was well known. Salim obtained his fuel from the aforementioned Zawiya refinery and then trucked the fuel to Zuwara (approximately $75 \mathrm{~km}$ ) and Abu Kammash (approximately $150 \mathrm{~km}$ ) before using pumping stations 
to bunker fuel to small fishing boats at sea. The use of the gasoil for the fishing boats' motors presents a means of explaining why the gasoil is loaded onto the boats. Those fishing boats would then bunker the fuel to tankers at sea, mixing the Libyan fuel with the existing fuel on the boat.

To evade detection, the boats undertook measures such as deactivating their GPS tracking (a legal requirement to keep active) and undertook complex manoeuvres to mask the products that they collected (Frattini: 2016). In the case of three shipments identified in investigative reports, the tankers were chartered by two Maltese businessmen and subsequently bunkered in Malta in storage tanks leased by a Swiss company. That Swiss company paid the Maltese businessmen for the fuel (Trial International: 2020). The Maltese businessmen in question are currently undergoing prosecution. The prosecutors in the case allege that the fuel was subsequently transported to Italy and adulterated. Approximately $\$ 35$ million of gasoil has reportedly been identified in the shipments in question (Corriere del Mezzogiorno: 2017). Increased surveillance and international attention on maritime smuggling of fuel has increased as a result of Operation Dirty Oil. Maritime smuggling from Libya seems subsequently to have reduced.

The result of these dynamics is that smuggling dynamics are no longer dependent on cross border movements. Cross-border smuggling of fuel from Libya is likely to have reduced, but diversion from the local Libyan market has significantly increased. Cross-border smuggling was predicated on retailing and generating a margin from one side of the border to another; i.e., buying at the subsidised rate and selling at a profit on the other side of the border in Tunisia, Egypt, Chad, Sudan and Niger. Now, however, the profit is increasingly obtained from Libyans themselves, as more of the fuel is diverted from the supply chain owing to weaknesses at the upstream, midstream and downstream levels. This means that, despite the state's buying greater amounts of fuel, less fuel is reaching the petrol pump at the official subsidised rates. This means that many Libyans are consequently forced to buy at higher, black market rates.

\section{Engaging with fuel smuggling: how to plug the leaks?}

The diversion and subsequent smuggling of petroleum products affects petroleum sectors across the world. There are a series of policies designed to combat it, ranging from attempts to reduce profitability, improve surveillance and transparency and rule-of-law centred efforts.

\section{Reduce the incentives}

Smugglers of oil products calculate the risk versus reward of their activities in part through the lens of profitability. One simple answer to reduce the prevalence of fuel smuggling is, therefore, to reduce that profitability. In countries with large subsidy regimes for fuels, this means cutting those subsidies. Iran has been implementing reforms to fuel subsidies since 2007. The price of gasoline was trebled by Iranian authorities through the removal of subsidies in 2019. This has concomitantly reduced the scale of smuggling. Studies assessing the price elasticity of gasoline prices in Iran also agree that the removal of subsidies will reduce the amount of gasoline that is smuggled across Iran's borders (Ghoddusi and Rafizadeh: 2019: 1).

The removal of subsidies is, however, not an economic silver bullet and can have negative impacts upon populations. Of course, price differentials can also be generated through other market variations, such as currency exchange rates. This is why the scale of the profits for smuggling fuel from Venezuela to Colombia was so high. Critics of Iran's approach note that 
hyperinflation in Iran's currency as a result of international sanctions may soon recreate profit margins for fuel smugglers (Mohseni-Cheraghlou: 2019).

There is also an important distinction to be made between those smugglers whose operations are based solely on profiting from margins between different markets and those whose operations are predicated on theft. Those who are diverting oil products from the supply chain through theft will of course be impacted by reduced margins, but a margin is still present as a result of the lack of direct payment for the oil products that they obtain. Removing subsidies on Libyan fuels may even increase the margin available to those in the smuggling sector who are stealing from the supply chain as prices at the pump will increase significantly.

Moreover, while it may stand to reason that those who are retailing fuel through buying it in one state and selling in another will reduce their activities if the margin is reduced, such a calculation also rests upon the assumption that they may have other means of income to adopt. Those operating at the lowest echelon of the smuggling supply chain, like the truckers, may depend on the business for survival. In Ghana, fuel smugglers have responded to diminishing returns by seeking to smuggle in greater volume (Ralby: 2017: 84). Others have diversified. In Iran, levels of diesel smuggling skyrocketed after price increases to gasoline were implemented (Voice of America: 2020).

\section{Improving the transparency of the sector: papering over the cracks}

Another key facilitator of oil and fuel smuggling is a lack of transparency within the oil sector of the states that suffer from the problem: poor reporting and entrenched corruption enable the activities of smugglers.

Fuel marking, where isotopes are added to fuel to allow investigators to ascertain where the fuel was intended to be sold, has become an increasingly prominent countermeasure, and is now mandated by law in many countries (Ralby: 2017: p. 87). In Northern Ireland, the 2015 addition of an isotope marker to fuel supplies allows authorities to understand quickly whether the fuel is rebated or unrebated. The standard 'washing' practices of the fuel smugglers do not remove the marker. UK authorities have observed a downward trend in the number of fuel laundering plants uncovered following its introduction. However, it is noteworthy that fuel smugglers have resorted to "sophisticated, and often dangerous" methods to defeat the marker that create toxic waste as a byproduct (Cross Border Organised Crime Threat Assessment: 2018: p. 16). Such waste has been dumped in remote locations, illustrating that the practice of fuel adulteration remains ongoing (Armaghi: 2018). Other contexts have reported successes from fuel marking. Mozambique's authorities reported the recovery of $\$ 25$ million in lost revenues and $\$ 650,000$ in asset seizures in the first semester of implementation of its marking programme (Wilcox: 2020).

Further strategies, such as GPS tracking of fuel trucks have been adopted to increase transparency in the system. Yet, such approaches have proven more open to manipulation by smugglers. In a particularly prominent illustration of this in Uganda, the trackers were given to another person on a motorcycle who would drive the route the truck was supposed to have taken to imitate the licit route. Meanwhile, the truck was diverted to the black market. In this case, the Ugandan regulators had become dependent on the data provided by a fuel company that was engaging in fuel smuggling. The chief executive of the company was arrested in 2016 after being implicated following the arrest of a motorcyclist who was carrying a GPS tracker (Ralby: 2017: p. 89). 


\section{Enforcement, complicity and second-order effects}

Countries that have a greater capacity to enforce laws on the ground have demonstrated significant successes in limiting smuggling practices. The aforementioned efforts by the UK to mark fuel, combined with reforms to regulations and stiffened sentencing guidelines have delivered results. The UK authorities estimate that the illicit diesel market share in Northern Ireland fell from an estimated 19\% in 2005-2006 to 6\% in 2016-2017 (Cross Border Organised Crime Threat Assessment: 2018: p. 16). As noted, however, fuel smugglers have resorted to more sophisticated approaches to maintain their operations, and analysts warn that an increase in arbitrage opportunities for retailing fuels across the Northern Irish-Ireland border following the exit of the UK from the European Union could lead to a resurgence in smuggling practices (TheConversation: 2019).

The complicity of high-level officials, and sometimes their direct involvement in the smuggling of oil products can make countering the activities of smugglers an intractable problem for those committed to clamping down upon the practice. As noted, in countries such as Nigeria and Uganda, distribution of the rights to smuggle can be a key part of a political settlement, and therefore a guarantor of stability. In Nigeria, the support of elites profiting from smuggling has been obtained by candidates for the presidency to support their campaigns and then to help them to maintain their authority following their election. In northern Uganda, the case of the Opec Boys illustrates how the authorities can turn a relatively blind eye to the operations of smugglers, provided they did not rebel against the government. Such developments can lead to the deliberate maintenance of loop holes and governance flaws that prevent enforcement of the law.

Political leaders committed to reducing smuggling must contend with the limitations of their authority, particularly in conflict affected states. In operating environments such as Libya and Mexico, those seeking to disrupt fuel smuggling activities have a very difficult task. How can they contend with armed groups/sophisticated organised crime groups that have control of the territory they must operate within or move their goods through, in lieu of effective state forces?

In Mexico, a sustained multi-faceted offensive to reduce fuel theft is ongoing at the time of writing. The administration of Andrés Manuel López Obrador has shut down pipelines, made adjustments to the supply chain, arrested senior PEMEX executives, increased sentencing guidelines for fuel theft, deployed soldiers to guard infrastructure and unveiled a package of development spending to be targeted at the areas of the country where most pipeline theft is taking place. The Obrador Administration claims to have reduced pipeline theft by $90 \%$ as a result of the crack down, but analysts note that there are concerns over how long it can be sustained, arguing that organised crime groups are biding their time before striking back (Jones and Sullivan: 2019: pp. 14-15).

Indeed, it should be noted that such forces have the ability to fight back. In Libya, attempts by the National Oil Corporation to oust the Nasr Brigade from the Zawiya refinery led only days later to a mysterious electricity blackout as the electricity generating plant in the city shut down, resulting in $900 \mathrm{~km}$ of Libya's coastline being engulfed in darkness (Eaton: 2019). The commander of the Nasr Brigade is also subject to UN Sanctions for human trafficking, but he has retained his position. Here it is important to understand how the practice of fuel smuggling and rights to it operate in the context in question. Seeking to remove lucrative rent streams in the illicit economy without considering the responses of those who profit may stoke violence. 


\section{Conclusions}

The examples listed above illustrate that fuel smuggling is not simply a practice conducted by small actors at the end of the supply chain through the movement of jerry cans on the back of a pickup. While such practices obviously exist, fuel smuggling operations also comprise complicit international companies, high level representatives of the state - civilian and military - and can take place in tankers at significant scale. Analysis of fuel smuggling activities in different contexts reveals inextricable connections with theft and exposes a range of challenges, from market incentives, to flaws in the governance of the oil sector, limitations to the control of formal state forces, and complicity of state employees in smuggling operations. It also illustrates that, for some segments of populations - particularly those actors who are involved in the downstream elements of the supply chain - smuggling provides income where few alternatives may exist.

The lessons from attempts to curb the smuggling of petroleum products to date indicate that a detailed assessment of the political economy of the sector must be undertaken to understand who profits and how, and to explore how they might respond. The higher the penetration of profiteers up the supply chain, the more complex the solutions become.

Effective strategies therefore need to be multifaceted and sequenced with other policies such as cash payments to populations in return for the removal of subsidies and private sector development opportunities - to offset the negative impacts of curbing of such activities on key actors and local communities. The latter must also avoid unduly rewarding illicit activity while also developing a pragmatic course of action that has a realistic chance of successful implementation. Finally, the transnational nature of the smuggling networks indicates that there will always be limits to any country-level strategy. International collaboration, and collaboration with neighbouring states in particular, should be made a priority.

\section{References}

African Development Bank (2016). Illicit trade in natural resources in Africa. https://www.afdb.org/ fileadmin/uploads/afdb/Documents/Events/IFF/Documents_IFF/ANRC_ILLICIT_TRADE_IN_ NATURAL_RESOURCES.pdf

Armaghi (2018). Fuel launderers who dumped toxic waste near Keady 'beneath contempt'. https:// armaghi.com/news/keady-news/fuel-launderers-who-dumped-toxic-waste-near-keady-beneath-contempt/72176

Assad, A. (2017). Audit bureau: Libya spent $\$ 30$ billion on fuel subsidies in five years. Libya Observer, 19 August 2017, https://www.libyaobserver.ly/economy/audit-bureau-libya-spent-30-billion-fuel-subsidies-five-years

Faucon, B. (2014). Tiny Ghana oil platform's big output sparks scrutiny. Wall Street Journal. 28 August 2014. http://www.wsj.com/articles/tiny-ghana-oil-platforms-big-output-sparks-scrutiny-1408669517.

Burgis, T. (2015). The Looting Machine: Warlords, Tycoons, Smugglers and the Systemic Theft of Africa's Wealth. William Collins.

Corriere del Mezzogiorno (2017). Gasolio rubato in Libia da miliziani dell'Isis e rivenduto in Italia ed Europa: 6 arresti. https://corrieredelmezzogiorno.corriere.it/catania/cronaca/17_ottobre_18/gasolio-rubatolibia-venduto-italia-ed-europa-nove-arresti-73d0b250-b3cb-11e7-a16e-c85a3b50cb84.shtml

Eaton, T. (2018). Libya's War Economy: Predation, Profiteering and State Weakness. Chatham House. https:// www.chathamhouse.org/publication/libyas-war-economy-predation-profiteering-and-state-weakness

Eaton, T. (2019). Libya: Rich in Oil, Leaking Fuel. Chatham House. https://chathamhouse.sho rthandstories.com/libya-rich-in-oil-leaking-fuel/index.html

Eaton, T. et al. (2019). Conflict economies in the Middle East and North Africa. Chatham House. https:// www.chathamhouse.org/sites/default/files/2019-08-13-ConflictEconomies.pdf

Frattini, D. (2016). Quelle petroliere fantasma dalla Libia all'Italia I traffici nel Mediterraneo (e i Big Data per tracciarli) [Ghost Tankers from Libya to Italy: Trades in the Mediterranean (and Big Data to track 
them)], Corriere Della Sera, 25 February 2016. http://www.corriere.it/reportage/esteri/2016/ quelle-petroliere-fantasma-dalla-libia-allitalia-i-traffici-nel-mediterraneo-e-i-big-data-pertracciarli/?refresh_ce-cp

Gallien, M. (2020). Informal Institutions and the regulation of smuggling in North Africa. Perspectives on Politics, 18(2), 492-508. doi:10.1017/S1537592719001026

Ghoddusi, H. and Rafizadeh, N. (2019). The Effect of Fuel Subsidy Reforms on the Behavior of Gasoline Consumers. University of Cambridge. http://www.econ.cam.ac.uk/people-files/faculty/km418/IIEA/ IIEA_2019_Conference/Papers/Rafizadeh\%20-\%20The\%20Effect $\% 20$ of $\% 20$ Fuel $\% 20$ Subsidy \%20Reforms\%20on\%20the\%20Behavior\%20of\%20Gasoline\%20Consumers.pdf

Irish Times (2002). Major fuel smuggling in North, says audit office. 15 February. https://www.irishtimes. com/news/major-fuel-smuggling-in-north-says-audit-office-1.413617

Jones, N.P. and Sullivan, J.P. (2019). Huachicoleros. Journal of Strategic Security, 12(4), 1-24. doi: https:// www.jstor.org/stable/10.2307/26851258

Katsouris, C. and Sayne, A. (2013). Nigeria's Criminal Crude: International Options to Combat the Export of Stolen Oil. Chatham House. https://www.chathamhouse.org/sites/default/files/public/Research/ Africa/0913pr_nigeriaoil_es.pdf

Lecoutere E. and Titeca K. (2007). The Opec Boys and the Political Economy of Smuggling in Northern Uganda. Brighton: The Institute of Development Studies, University of Brighton.

Lipin, M. et. al. (2020). Iran's November Gas Price Hike Fails to Ease Fuel Smuggling to Pakistan. Voice of America. 15 February 2020. https://www.voanews.com/middle-east/voa-news-iran/iransnovember-gas-price-hike-fails-ease-fuel-smuggling-pakistan

Mining.com (2017). Just How Big is the Oil Market? https://oilprice.com/Energy/Crude-Oil/The-OilMarket-Is-Bigger-Than-All-Metal-Markets-Combined.html

Mohseni-Cheraghlou, A. (2019). Déjà vu all over again: The three "I"s of gasoline subsidies and social unrest in Iran: Middle East Institute. https://www.mei.edu/publications/deja-vu-all-over-againthree-gasoline-subsidies-and-social-unrest-iran

Northern Ireland Assembly (2012). Official Report: 2011-2: Hansard. http://www.niassembly.gov.uk/ assembly-business/official-report/committee-minutes-of-evidence/session-2011-2012/october-2011/ northern-ireland-organised-crime-strategy-2012-15/

Pack, J. (2021, forthcoming). Libya and the Global Enduring Disorder. London: Hurst.

Ralby, I.M. (2017). Downstream oil theft: global modalities, trends, and remedies. Atlantic Council. https://www.atlanticcouncil.org/wp-content/uploads/2017/01/Downstream_Oil_Theft_web_ 0327.pdf

Rosenberg, M. (2011). Mexico's Pemex sues U.S. firms over fuel smuggling. Reuters. https:// www.reuters.com/article/us-mexico-pemex-idUSTRE7516S420110602

The Conversation (2019). Smuggling in the Irish borderlands - and why it could get worse after Brexit. https://theconversation.com/smuggling-in-the-irish-borderlands-and-why-it-could-get-worse-afterbrexit-111153

Trial International (2020). Smuggling Libyan gasoil: a Swiss trader navigates through troubled waters. https://trialinternational.org/latest-post/smuggling-libyan-gasoil-a-swiss-trader-navigates-throughtroubled-waters/

UK Government (2018). Cross Border Organised Crime Assessment. https://www.justice-ni.gov.uk/ publications/cross-border-organised-crime-assessment-2018

Wilcox, M. (2020). Will fuel marking spell the end of fuel smuggling in Africa? Africa Times. 31 March. https://africatimes.com/2020/03/31/will-fuel-marking-spell-the-end-of-fuel-smuggling-in-africa/ 